\title{
Ubiquitous Hub for Digital Natives
}

\author{
http://dx.doi.org/10.3991/ijet.v11i02.4993
}

\author{
Mohd Shafie Rosli, Nor Shela Saleh, Baharuddin Aris, Maizah Hura Ahmad and Shaharuddin Md. Salleh \\ Universiti Teknologi Malaysia, Johor Bahru, Malaysia
}

\begin{abstract}
This study was conducted to construct a model on ubiquitous hub for digital natives. Respondents were 250 digital native generation students, from a higher learning institution in Malaysia. The result of the regression, structural equation model and path analysis revealed that multitask as well as gratification and reward nurture digital natives to learn in ubiquitous computing environment. Digital natives characteristics of reliant on graphic for communication, and attitude toward technology are rejected from the model based on the statistical evidence. Test of the relationship between multitask toward gratification and reward via structural equation model shows that both influence each other. Conclusion on the set-up of ubiquitous hub for digital natives based on the model derived are discussed.
\end{abstract}

Index Terms-Digital Natives, Gratification, Multitask, Path Analysis, Reward, Structural Equation Model, Ubiquitous

\section{INTRODUCTION}

Research about digital natives had started to gain its momentum since the terms digital natives and digital immigrants were introduced by Prensky (2001). The digital natives is a terminology widely uses to describe the new generation of college students that had embedded so long in the technological entities such as tablets, smartphones, laptops and computers. Among the research that were done around the topic of digital natives are comparing the Internet use, Internet anxiety and Internet Identification between two generations of digital natives (Richard et al, 2013), modeling digital natives collaboration (Leppisaari and Lee, 2012), development of digital natives assessment scale (Teo, 2013), the use of social media among digital natives (Tkalac Vercic and Vercic, 2013), media preference of digital natives (Julia and Ana Tkalac, 2011) and building computer games as effective learning tools for digital natives (Silveira et al. 2011). Yet, few researches had focused on studying the relationship between digital natives and readiness to learn via ubiquitous computing.

Ubiquitous computing environment is currently the cutting edge and emerging development in educational technology, the factors that come from the nature of digital natives and its relationship with a readiness to learn via ubiquitous computing can shed light into factors that are exactly playing role in readiness to learn via ubiquitous computing. These will enable the construction on the model for ubiquitous hub for digital natives.

Among the research that was done in this digital natives and ubiquitous computing is an assessment of students' preferences in constructivist as did by Tsai, Tsai and Hwang (2011). However, what are the main factors in digital natives that are actually contributing toward the willingness, the readiness toward ubiquitous computing remain unknown. Therefore, a model on ubiquitous hub for digital natives is needed as a maneuver to accommodate future landscape of education and digital community.

\section{Problem Statement}

The rapid innovation of technologies had changed the nature how human typically learn either at school, at home even during leisure time. From the traditional top to down approach, the education had revolutionized toward active engagement and deep incorporation of cutting edge tools. Indeed, this post-modern age students having a sheer volume of interaction with these tools (Prensky, 2001). Some scholars even believe that students' brain structure has physically changed (e.g. Rosli, Aris \& Ahmad, 2015). Medical researcher in the field of neural plasticity found that human brains change in response to repeated experiences (Maguire, Woollett and Spiers, 2006. This might be the reason why digital natives are different from the digital immigrants. Yet, something for true is that how today's students think and process information is fundamentally different from the older generation. This is the digital natives, information age generation. Recently, the digital natives of our students have drawn increasing attention from educators and researchers (Morgan et al. 2000; Tsai, Tsai and Hwang, 2011; Teo, 2013).

Yet, few researches had focused on studying the relationship between digital natives and readiness to learn via ubiquitous computing in order to produce a sustainable model that is used in production of any new emerging media for the purpose of using by these digital natives.

From literature, ubiquitous computing had been deeply implemented into the education system (Tsai, Tsai and Hwang, 2013). The ubiquitous computing has the ability to support seamless learning and the ability to flex on adjustable models of learning materials (Ogata and Yano, 2004; Yang et al. 2008). The incorporation of ubiquitous computing had been accelerated by its similarity with constructivist epistemology (Chu et al. 2010; Hwang et al. 2008). Despite the immense volume of interaction by the digital natives with ubiquitous computing, few past research had ever investigated the factors inside the digital nativeness badges and its relationship between the readinesses to learn via ubiquitous computing. This information is vital in order to design our currently emerging ubiquitous computing to cope with the badges of these digital natives. The data is going to play a very imperative role in designing the adaptive guidance for ubiquitous computing users.

Research has been conducted in developing mobile application for the purpose of research as the world is currently as the beginning of the third paradigm computing via ubiquitous (e.g. Maya et al. 2013; Alex, 2013; Evgeny, 2013). Tablets and smartphones are now at the center of locus for new research in educational technology through the known as mobile application (e.g: Siti Khadijah et al. 
2013; Sonmez et al. 2013). However, it was reported that mobile application giving impact far less than anticipated as the developed mobile application was failed to be used optimally as there are no clear framework and guideline for the development of mobile application as found by (Sonmez et al. 2013) to accommodate the ubiquitous computing environment.

\section{LITERATURE REVIEW}

\section{A. Digital Natives Attributes}

Thompson (2015) found that digital natives aware about the influence of technology, not only to their lives but also toward their learning. The author concluded that via the structured interview done to eight digital natives, digital natives alert about the drawbacks of constant engagement in technology. Digital natives are unlike digital immigrants perceive technology differently (Metallo and Agrifoglio, 2015), that make them as unique and tied closer toward technology. The scenario evolves due to students who born after 1980's have been brought up in environment embedded by technologies (Thang et al. 2014).

Prensky (2001) describes digital natives as compelling multitasking, due to their preference for speed and nonlinear processing. Some might even unable to bear a slowpaced environment (Tapscott, 2009). Digital natives consider multitasking as natural, highly comfortable to have the ability to multitask and majority of digital natives are multitasking (Ugras and Gulsecen, 2013).

The technological environment that digital natives had emerged for so long influence their preference. Emoticons in communication of adolescent and emerging adults' is the result of bonding experience with IM (Sherman, Michikyan and Greenfield, 2013). School students in New Zealand regard emoticons as imperative in online interaction (Loewen and Reissner, 2015).

Newer media manipulate gratification as its captological advantage. Malik, Dhir and Nieminen (2015) found that in India, gratification is playing role in digital natives usage of social media. Gratification is implanted through specific design characteristics to incite intrinsic motivations (Hamari and Koivisto, 2015).

Analysis of the literature shows that digital natives are synonym with positive attitude or perspective toward technology, confortable with multitasking, use graphic in communication and demand gratification as well as rewards. However, these exclusive appearances of digital natives may render them incapable of deep learning and productive work as technologies might be a factor of distraction (Bauerlein, 2008).

\section{B. Ubiquitous Computing Environment for Education}

Ubiquitous computing gained its attractiveness as collateral effect of mobile technology (Huang and Chiu, 2015). Ubiquitous pave way to a new paradigm of education that derives anywhere and anytime learning environment (Joseph, 2012).

Research conducted on the hardware structure for ubiquitous classroom (Bargaoui and Bdiwi, 2014) as well as integration of wireless technologies to support a campus (Khamayseh et al. 2014). Review on software for the ubiquitous classroom, such as Youubi (De Sousa Monteiro, Gomes and Mendes Neto, 2015) and Arduino (Cuartielles, 2015) has been done. Yet, few researchers are actually probe into what is actually the attributes of digital natives that actually lead to their readiness to learn with ubiquitous computing environment.

\section{RESEARCH OBJECTIVES}

Research objectives are:

1. To investigate on the perspective about technology among digital natives.

2. To investigate on the comfortableness with multitasking among digital natives.

3. To investigate on the reliant on graphic for communication among digital natives.

4. To investigate on the thrive on gratification and rewards among digital natives.

5. To investigate on the readiness to learn via ubiquitous computing among digital natives.

6. To construct a model on readiness to learn via ubiquitous computing by digital natives.

\section{RESEARCH METHOdOLOGY}

The research design for this research is survey. The questionnaire was developed according to five constructs labeled as attitude toward technology, comfortable with multitasking, reliant on graphic for communication, dependent on instant reward as well as readiness to study via ubiquitous computing.

Five stages of Likert's scale were implemented as $1=$ strongly not agree, $2=$ not agree, $3=$ fair, $4=$ agree and eventually $5=$ strongly agree. The questionnaire is the product of adaptation of the literature, therefore, a pilot study was conducted on 12 respondents from the same institution. The 12 respondents were later excluded from being sampled during data collection. The summary of this instrument is as in Table I.

TABLE I.

INSTRUMENT ITEMS AND CONSTRUCT

\begin{tabular}{|c|l|c|l|}
\hline Part & \multicolumn{1}{|c|}{ Construct } & Item & \multicolumn{1}{c|}{ Reference } \\
\hline A & Demographic Information & $1-4$ & $\begin{array}{l}\text { Constructed by re- } \\
\text { searchers }\end{array}$ \\
\hline B & $\begin{array}{l}\text { Attitude toward technolo- } \\
\text { gy }\end{array}$ & $5-10$ & $\begin{array}{l}\text { Adaption from Teo } \\
(2013)\end{array}$ \\
\hline C & $\begin{array}{l}\text { Comfortable with multi- } \\
\text { tasking }\end{array}$ & $11-16$ & $\begin{array}{l}\text { Adaption from Teo } \\
(2013)\end{array}$ \\
\hline D & $\begin{array}{l}\text { Reliant on graphic for } \\
\text { communication }\end{array}$ & $17-24$ & $\begin{array}{l}\text { Adaption from Teo } \\
(2013)\end{array}$ \\
\hline E & $\begin{array}{l}\text { Instant gratification and } \\
\text { rewards }\end{array}$ & $25-34$ & $\begin{array}{l}\text { Adaption from Teo } \\
(2013)\end{array}$ \\
\hline F & $\begin{array}{l}\text { Readiness to learn via } \\
\text { ubiquitous computing }\end{array}$ & $35-43$ & $\begin{array}{l}\text { Adaptation from } \\
\text { McVay (2001) }\end{array}$ \\
\hline
\end{tabular}

The population is students from a higher education institution in Malaysia who born between 1990 to 1994 The institution was sampled using simple random sampling technique. Respondents were also sampled via simple random sampling technique. The sample size is 250 respondents, determined by Krejcie and Morgan's Table.

\section{Data ANALYSiS}

To understand the descriptive nature of the data, item was analyzed for its mean value and standard deviation value. Later, mean values for each construct were evaluated. As a mechanism to shed light into the relationship 
between digital natives and ubiquitous, regression was computed. The data, then used to construct a framework for this research. To ensure the precision of the framework, it later was tested using structural equation model (SEM) and path analysis technique.

\section{A. Instrument Reliability}

The reliability of the instrument is Cronbach's Alpha = .952. The pilot test was done to 12 respondents using an internal consistency technique. Only items from part B, C, $\mathrm{D}, \mathrm{E}$ and $\mathrm{F}$ from Table I was tested. Items from part $\mathrm{A}$ were excluded as its involve only demographic data. Details on the reliability test is as in Table II.

Relying on the reliability test result, no items have been dropped. Instrument validity was validated by a renown statistical and research methodology expert in Malaysia. Descriptive analysis shows the following result.

\section{B. Framework Construction}

The framework on ubiquitous hub for digital natives is as in Figure 1. The data in Table III were used to construct the framework.

TABLE II.

INSTRUMENT'S RELIABILITY

\begin{tabular}{|c|c|c|c|c|}
\hline Item & $\begin{array}{c}\text { Scale } \\
\text { Mean if } \\
\text { Item } \\
\text { Deleted }\end{array}$ & $\begin{array}{c}\text { Scale } \\
\text { Variance if } \\
\text { Item Delet- } \\
\text { ed } \\
\end{array}$ & $\begin{array}{c}\text { Corrected } \\
\text { Item-Total } \\
\text { Correlation }\end{array}$ & $\begin{array}{c}\text { Cronbach's } \\
\text { Alpha if } \\
\text { Item Deleted }\end{array}$ \\
\hline 5 & 153.33 & 320.606 & .457 & .951 \\
\hline 6 & 153.50 & 318.636 & .408 & .951 \\
\hline 7 & 153.83 & 308.879 & .659 & .949 \\
\hline 8 & 153.83 & 299.242 & .737 & .949 \\
\hline 9 & 154.08 & 300.992 & .711 & .949 \\
\hline 10 & 154.08 & 308.265 & .512 & .951 \\
\hline 11 & 153.67 & 311.152 & .754 & .949 \\
\hline 12 & 153.75 & 309.841 & .697 & .949 \\
\hline 13 & 153.67 & 311.515 & .738 & .949 \\
\hline 14 & 153.75 & 310.568 & .669 & .949 \\
\hline 15 & 153.83 & 310.152 & .722 & .949 \\
\hline 16 & 154.00 & 312.727 & .599 & .950 \\
\hline 17 & 154.25 & 306.205 & .839 & .948 \\
\hline 18 & 154.17 & 309.970 & .547 & .950 \\
\hline 19 & 154.08 & 302.447 & .819 & .948 \\
\hline 20 & 154.08 & 300.992 & .779 & .948 \\
\hline 21 & 154.00 & 309.273 & .735 & .949 \\
\hline 22 & 154.00 & 308.364 & .662 & .949 \\
\hline 23 & 154.25 & 306.568 & .633 & .950 \\
\hline 24 & 154.50 & 299.727 & .744 & .949 \\
\hline 25 & 153.83 & 302.879 & .697 & .949 \\
\hline 26 & 154.08 & 321.538 & .289 & .952 \\
\hline 27 & 153.67 & 319.697 & .377 & .951 \\
\hline 28 & 154.25 & 307.659 & .782 & .949 \\
\hline 29 & 154.17 & 312.152 & .479 & .951 \\
\hline 30 & 153.67 & 316.061 & .536 & .950 \\
\hline 31 & 153.50 & 320.273 & .447 & .951 \\
\hline 32 & 153.58 & 316.629 & .497 & .950 \\
\hline 33 & 153.58 & 320.992 & .415 & .951 \\
\hline 34 & 153.58 & 320.992 & .415 & .951 \\
\hline 35 & 154.17 & 318.879 & .470 & .951 \\
\hline 36 & 154.17 & 315.061 & .523 & .950 \\
\hline 37 & 154.25 & 321.477 & .316 & .951 \\
\hline 38 & 154.17 & 318.515 & .325 & .952 \\
\hline 39 & 153.92 & 320.447 & .335 & .951 \\
\hline 40 & 154.08 & 322.447 & .205 & .952 \\
\hline 41 & 154.00 & 314.545 & .527 & .950 \\
\hline 42 & 154.17 & 321.061 & .363 & .951 \\
\hline 43 & 154.50 & 316.273 & .508 & .950 \\
\hline
\end{tabular}

As illustrated by Figure 1, only the comfortableness with multitask as well as thrive on gratification and rewards show significant regression value. The insignificant variables were drawn using dot-line and dot-box.

\section{Model Construction}

The framework was later tested via AMOS to reevaluate the framework and for the purpose of structural model construction. The assignation of constructs and variables is as in Table IV.

Using AMOS with construct and variable properties as in Table IV, a structural model was constructed. The structural model constructed is as in Figure 2.

The residual, e $1=.31$ signifying that 31 percent of the relationship between the excogenous and endogenous variables are not characterized by the model. As framework in Figure 1 was fabricated by correlation, the Standardized Regression Weight with support from Regression Weight is used instead of Unstandardised Correlation Coefficients. The Standardized Regression Weight is as in Table V and Regression Weight as in Table VI.

TABLE III. DESCRIPTIVE DATA

\begin{tabular}{|l|c|c|c|}
\hline \multicolumn{1}{|c|}{ Research Objective } & Construct & Mean & S.D \\
\hline $\begin{array}{l}\text { To investigate on the perspective } \\
\text { about technology among digital na- } \\
\text { tives. }\end{array}$ & $\begin{array}{c}\text { Attitude toward } \\
\text { technology }\end{array}$ & 3.95 & .77 \\
\hline $\begin{array}{l}\text { To investigate on the comfortableness } \\
\text { with multitasking among digital } \\
\text { natives. }\end{array}$ & $\begin{array}{c}\text { Comfortability } \\
\text { with multitasking }\end{array}$ & 3.89 & .76 \\
\hline $\begin{array}{l}\text { To investigate on the reliant on graph- } \\
\text { ic for communication among digital } \\
\text { natives. }\end{array}$ & Reliant on reward & 3.50 & .79 \\
\hline $\begin{array}{l}\text { To investigate on the thrive on gratifi- } \\
\text { cation and rewards among digital } \\
\text { natives. }\end{array}$ & $\begin{array}{l}\text { Instant gratifica- } \\
\text { tion and rewards }\end{array}$ & 3.95 & .64 \\
\hline $\begin{array}{l}\text { To investigate on the readiness to } \\
\text { learn via ubiquitous computing among } \\
\text { digital natives. }\end{array}$ & $\begin{array}{l}\text { Readiness to learn } \\
\text { via ubiquitous } \\
\text { computing }\end{array}$ & 3.58 & .69 \\
\hline
\end{tabular}

TABLE IV.

RESEARCH CONSTRUCTS AND VARIABLES PROPERTIES IN AMOS

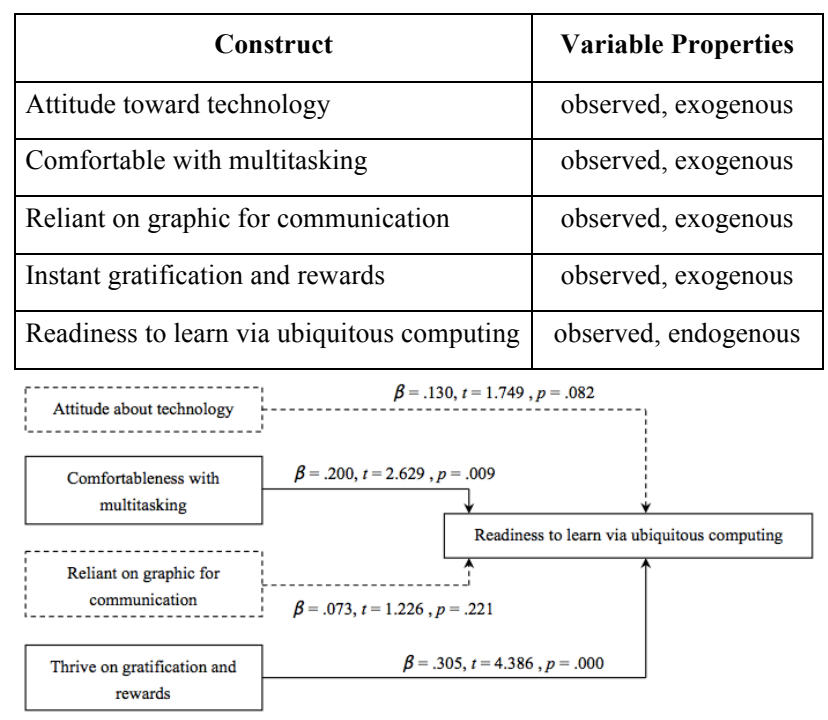

Figure 1. The framework on ubiquitous hub for digital natives 


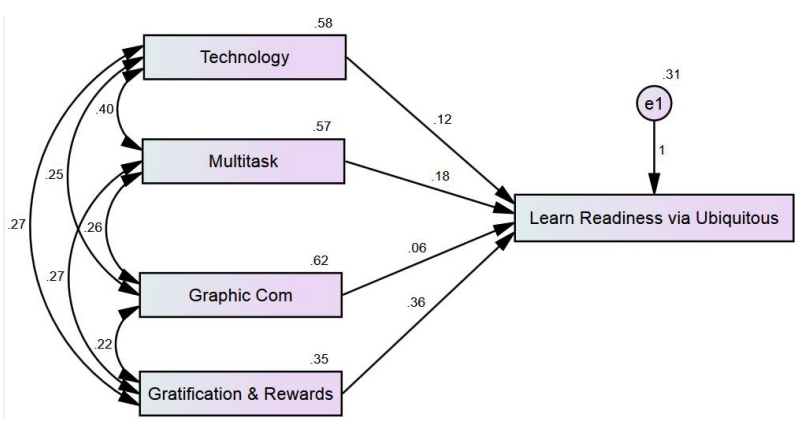

Figure 2. The structural model

TABLE V.

STANDARIZED REGRESSION WEIGHT FROM AMOS

\begin{tabular}{|c|c|}
\hline Regression & Estimate \\
\hline $\begin{array}{l}\text { Readiness to learn via } \\
\text { ubiquitous computing }\end{array} \quad$ Technology & .130 \\
\hline $\begin{array}{l}\text { Readiness to learn via } \\
\text { ubiquitous computing }\end{array} \longrightarrow$ Multitask & .200 \\
\hline$\longrightarrow$ Graphic & .073 \\
\hline $\begin{array}{l}\text { Instant } \\
\text { Gratification \& } \\
\text { Reward }\end{array}$ & .305 \\
\hline
\end{tabular}

TABLE VI.

REGRESSION WEIGHT FROM AMOS

\begin{tabular}{|l|c|c|c|}
\hline \multicolumn{2}{|c|}{ Regression } & C.R. & P \\
\hline $\begin{array}{l}\text { Readiness to learn via } \\
\text { ubiquitous computing }\end{array}$ & Technology & 1.763 & .078 \\
\hline $\begin{array}{l}\text { Readiness to learn via } \\
\text { ubiquitous computing }\end{array}$ & Multitask & 2.650 & .008 \\
\hline $\begin{array}{l}\text { Readiness to learn via } \\
\text { ubiquitous computing } \\
\text { cation }\end{array}$ & $\begin{array}{c}\text { Graphic } \\
\text { Communi- }\end{array}$ & 1.236 & .216 \\
\hline $\begin{array}{l}\text { Readiness to learn via } \\
\text { ubiquitous computing }\end{array}$ & $\begin{array}{c}\text { Instant } \\
\text { Gratification } \\
\text { \& Reward }\end{array}$ & 4.220 & .000 \\
\hline \multicolumn{3}{|c}{} \\
\hline
\end{tabular}

Based on data in Table V and Table VI, there are only two significant regression relationship. Comfortableness with multitask toward readiness to learn via ubiquitous computing $(\beta=.130$, C.R. $=1.763, p<0.05)$, and thrive on instant gratification and reward toward readiness to learn via ubiquitous computing $(\beta=.305$, C.R. $=4.220, p$ $<0.05)$.

According to the path analysis done as in Table $\mathrm{V}$ and Table VI and comparison with the data from the framework on readiness to learn via ubiquitous computing by digital natives (Figure 1). The researcher had come out with the model on readiness to learn via ubiquitous computing as in Figure 3.

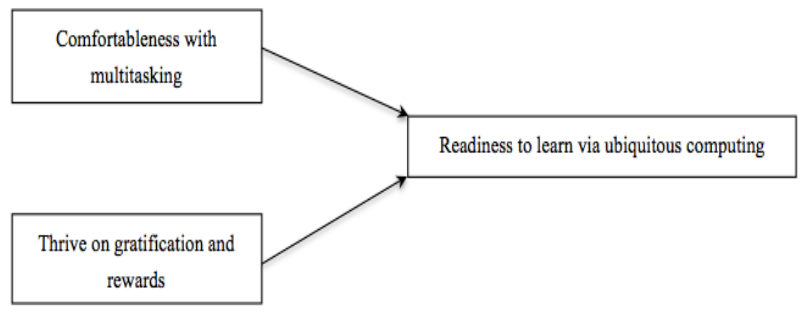

Figure 3. The model on ubiquitous hub for digital natives

\section{Post-Hoc Analysis of the Independent Variables}

To probe into the relationship between independent variables, the data on covariances and correlations from the structural equation model was manipulated.

TABLE VII.

COVARIANCE DATA FROM STRUCTURAL MODEL (FIGURE 2)

\begin{tabular}{|l|c|c|}
\hline & C.R. & P \\
\hline Multitask $\longleftrightarrow$ Gratification \& Reward & 8.132 & .000 \\
\hline
\end{tabular}

TABLE VIII

CORRELATION DATA FROM STRUCTURAL MODEL (FIGURE 2)

\begin{tabular}{|l|c|}
\hline & Estimate \\
\hline Multitask $\longleftrightarrow$ Gratification \& Reward & .601 \\
\hline
\end{tabular}

A strong relationship exists between comfortableness with multitasking and thrive on gratification and rewards $(\mathrm{r}=.601, \mathrm{C} . \mathrm{R} .=8.132, \mathrm{p}<0.05)$. Indicates that both variables influencing each other.

\section{DISCUSSION}

Multitasking has been well adopted by digital natives (Boruszko, 2013; Kirschner and Karpinski, 2010). In ubiquitous environment, multitasking is well supported (Cardoso-Leite, Green, \& Bavellier, 2015). Multitasking must be given a priority in designing ubiquitous hub in the future. However, some of the hardware's ability to multitask is beyond instructor control. Yet, the learning environment uses for learning engagement can be customized and designed by the instructor even at its very early stage of development. Web learning environment must be tuned to support multi-tab navigation. For mobile application, the navigation architecture has to be based on tabbed view architecture.

Beyond the learning environment perspective, the usage of cloud technology will encourage the digital natives. Cloud enables them to engage several hardware simultaneously. Render multitasking more than possible. Using computer, desktop, smartphone and tablet with multitask supporting hand gesture might serve as a significant perspective by the digital natives. Still, there is lack of research on how multitasking gestures influence digital natives.

Reward is common in education (Raupach et al. 2013; Barret \& Toma, 2013) and gratification had gained the attention of educational researcher recently (e.g. Herndon, Bembenutty \& Gill, 2015; Ponce, Polasko \& Molina, 2015; Sarapin \& Morris, 2015; Nicholas Gerlich et al. 2015; Liu, 2015). What is actually the kind of reward? And how reward impacting the digital natives? Yet remain puzzling as lack of research is actually looking at that point. One point to be sure, reward is a vital element for digital natives in ubiquitous computing environment.

Ubiquitous computing that offers gratification drive the digital natives to engage the ubiquitous environment greater. Mantymaki \& Riemer (2014) found that hedonic gratification offer by virtual environment to the digital natives replace experience gained from the real world. For surfing the Internet, no difference in gratification exists between digital natives and their immigrant counterparts (Salman \& Rahim, 2012). Thus, in designing an environ- 
ment for digital natives is complicated. The designer should design the learning environment to be offering a tremendous amount of hedonic gratification to ensure engagement. The web, can remain as it was.

Digital natives need both multitask as well as gratification and reward. Both cannot be offered separately to the digital natives. If a digital native has high tendency toward gratification and reward, directly his or her tendency toward multitask is also high and vice-verca. A modular ubiquitous computing environment might suit the need of digital natives as it offers upgradable multitasking capabilities and any newer gratification and reward can be add-on later.

\section{VIII.CONCLUSION}

To set-up an effective ubiquitous hub for digital natives, the hardware must be multitask capable especially with hand gesture support. The web site must support multitab navigation and mobile application or learning environment should embrace tabbed-view architecture. Integration of cloud technology into the ubiquitous hub is also recommended to further enable multitask.

Digital natives also require reward even in ubiquitous hub. Further research on reward in ubiquitous hub a current research gap that should be pointed at. Design of ubiquitous learning environment or the hub itself must offer gratification. However, what is the gratification for digital natives in ubiquitous environment need a further study.

Two factors influence digital natives toward ubiquitous computing, which are ability to multitask and the offer of gratification and reward. Multitask, gratification and reward must be serve as a package to the digital natives instead of as a separate module of package. A modular ubiquitous computing might fulfill this requirement. Thus, any future ubiquitous product is recommended to be modular-enable.

\section{ACKNOWLEDGMENT}

The authors would like to thank Universiti Teknologi Malaysia (UTM) and Ministry of Higher Education Malaysia for their support in making this project possible. This work was supported by Research University Grant Scheme (Q.J130000.2631.11J09) initiated by UTM and MoE.

\section{REFERENCES}

[1] Prensky, M., Digital Natives Digital Immigrants. On The Horizon. MCB University Press, 2001.

[2] Richard, J.E. and Meuli, P.G. "Exploring and Modelling Digital Natives' Intention to Use Permission-based Location Aware Mobile Advertising". Journal of Marketing Management. 29 (5-6), pp. 698-719, 2013. http://dx.doi.org/10.1080/0267257X.2013. $\underline{770051}$

[3] Leppisaari, I., and Lee, O. "Modelling Digital Natives' International Collaboration: Finnish-Korean Experiences of Environmental Education". Educational Technology \& Society. 15 (2), pp. 244-256, 2012.

[4] Teo, T. "An Initial Development and Validation of a Digital Natives Assessment Scale (DNAS)". Computer \& Education. 67 (2013), pp. 51-57, 2013.

[5] Tkalac Vercic, A., and Vercic, D. "Digital Natives and Social Media". Public Relations Review. 39 (5), pp. 600-602, 2013. http://dx.doi.org/10.1016/j.pubrev.2013.08.008
[6] Julia, F. and Ana Tkalac, V. "Media Preferences of Digital Natives' Internal Communication: A Pilot Study”. Public Relations Review. 37 (2011), pp. 84-86, 2011.

[7] Silveira, I. F., de Araujo Jr., C. F., Sandro da Veiga, J. and Bezerra, L.N.M. "Building Computer Games as Effective Learning Tools for Digital Natives - and Similars". Issues in Informing Science and Information Technology. 8 (2011), pp. 77-92, 2011.

[8] Tsai, P.-S., Tsai, C.-C and Hwang, G.-J. "Developing a Survey for Assessing Preferences in Constructivist Context-Aware Ubiquitous Learning Environments". Journal of Computer Assisted Learning. 28 (2012), pp. 250-264. 2011.

[9] Prensky, M., Digital Natives Digital Immigrants. On The Horizon. MCB University Press, 2001.

[10] Rosli, M.S., Aris, B., and Ahmad, M.H. "Online Intellectual Transformation System”. Contemporary Engineering Sciences. 8 (1-4), pp. 39-47, 2015.

[11] Maguire, E.A., Woollett, K., and Spiers, H.J. "London Taxi Drivers and Bus Drivers: A Structural MRI and Neuropsychological Analysis". Hippocampus. 16 (2006), pp. 1091 - 1101, 2006.

[12] Morgan, K., Morgan, M. and Hall, J. "Psychological Developments in High Technology Teaching and Learning Environments". British Journal of Educational Technology, 31, pp. 71-79, 2000. http://dx.doi.org/10.1111/1467-8535.00136

[13] Tsai, P.-S., Tsai, C.-C and Hwang, G.-J. "Developing a Survey for Assessing Preferences in Constructivist Context-Aware Ubiquitous Learning Environments". Journal of Computer Assisted Learning. 28 (2012), pp. 250-264, 2011.

[14] Teo, T. "An Initial Development and Validation of a Digital Natives Assessment Scale (DNAS)". Computer \& Education. 67 (2013), pp. 51-57, 2013.

[15] Tsai, P.-S., Tsai, C.-C and Hwang, G.-J. "Developing a Survey for Assessing Preferences in Constructivist Context-Aware Ubiquitous Learning Environments". Journal of Computer Assisted Learning. 28 (2012), pp. 250-264, 2012.

[16] Ogata, H. and Yano, Y., "Knowledge Awareness Map for Computer-Supported Ubiquitous Language-Learning". Proceedings of the $2^{\text {nd }}$ IEEE International Workshop on Wireless and Mobile Technologies in Education, 2004.

[17] Yang, S. J. H., Okamoto T., and Tseng, S.S. "Context-Aware and Ubiquitous Learning”. Educational Technology \& Society. 11, pp. $1-2,2008$.

[18] Chu, H. C., Hwang, G. J. and Tsai, C.C. "A Knowledge Engineering Approach to Developing Mindtools for Context-Aware Ubiquitous Learning". Computers \& Education. 54, pp. 289-297, 2010. http://dx.doi.org/10.1016/j.compedu.2009.08.023

[19] Hwang, G.J., Tsai, C. C, and Yang S.J.H. "Criteria, Strategies and Research Issues of Context-Aware Ubiquitous Learning”. Educational Technology \& Society. 11, pp. 91-91, 2008.

[20] Maya, I., Matthew, M. T., James, D. S., and Wenonoa, S. "Fifth Graders as App Designers: How Diverse Learners Conceptualize Educational Apps". Journal of Research on Technology in Education. 46 (1), pp. 53 - 80, 2013. http://dx.doi.org/10.1080/15391 523.2013.10782613

[21] Alex, N. "Best Practices on the Move: Building Web Apps for Mobile Devices". Communication of the ACM. 56 (8), pp. 45 -51, 2013. http://dx.doi.org/10.1145/2492007.2492023

[22] Evgeny, K., Gabriel, G., Sebastien, B., and Marco, T. "Media Tablets for Mobile Learning". Communication of the ACM. 56 (11), pp. 68 - 75, 2013. http://dx.doi.org/10.1145/2500494

[23] Siti Khadijah, M., Zaidatun, T., Jamalludin, H., and Nurbiha, A. Shukor. "Pattern of Reflection in Learning Authoring System through Blogging". Computer \& Education. 69 (2013), pp. $356-$ 358, 2013.

[24] Sonmez, P., Recep, C., Mustafa, E., Bayram, Y. H., and Cemalettin, A. "The Use of Tablet PC and Interactive Board from the Perspectives of Teachers and Students: Evaluation of the FATIH Project". Educational Sciences: Theory \& Practice. 13 (3), pp. $1815-1822,2013$.

[25] Sonmez, P., Recep, C., Mustafa, E., Bayram, Y. H., and Cemalettin, A. "The Use of Tablet PC and Interactive Board from the Perspectives of Teachers and Students: Evaluation of the FATIH Project". Educational Sciences: Theory \& Practice. 13 (3), pp. $1815-1822,2013$. 
[26] Thompson, P. "How Digital Native Learners Describe Themselves". Education and Information Technologies. 20 (3), pp. 467 - 484, 2015. http://dx.doi.org/10.1007/s10639-013-9295-3

[27] Metallo, C., and Agrifoglio, R. "The Effects of Generational Differences on Use Continuance of Twitter: An Investigation of Digital Natives and Digital Immigrants". Behaviour and Information Technology. 34 (9), pp. 869 - 881, 2015. http://dx.doi.org/10.1080/0144929X.2015.1046928

[28] Thang, S.M., Jaafar, N.M., Nambiar, R.M.K. Amir, Z. and Wong, F.F. "Are Malaysian Undergraduates 'Digital Natives' in the True Sense of the Word? A Qualitative Analysis". 3L: Language, Linguistics, Literature. 20 (1), pp. 177 - 191, 2014.

[29] Prensky, M., Digital Game-Based Learning. McGraw-Hill, New York, 2001.

[30] Tapscott, D., Grown Up Digital: How the Net Generation is Changing Your World. McGraw-Hill, New York, 2009.

[31] Ugras, T. and Gulsecen, S. "Multitasking: Digital Natives' Interaction with New Media". Lectures Notes in Computer Science. 8019 (PART1), pp. 94 - 103, 2013. http://dx.doi.org/10.1007/9783-642-39360-0 11

[32] Sherman, L.E., Michikyan, M., and Greenfield, P.M. "The Effects of Test, Audio, Video, and In-Person Communication on Bonding Between Friends". Cyberpsychology. 7 (2), 2013. http://dx.doi.org/10.5817/CP2013-2-3

[33] Loewan, S. and Reissner, S. "A Comparison of Incidental Focus on Form in the Second Language Classroom and Chatroom". Computer Assisted Language Learning. 22 (2), pp. $101-114$, 2015. http://dx.doi.org/10.1080/09588220902778211

[34] Malik, A., Dhir, A. and Nieminen, M. "Uncovering Facebook Photo Tagging Culture and Practice among Digital Natives". Global Media Journal, 13 (24), pp. 22, 2015

[35] Hamari, J. and Koivisto, J. "Why Do People Use Gamification Services?” International Journal of Information Management. 35 (4), pp. 419 - 431, 2015. http://dx.doi.org/10.1016/j.ijinfomgt. 2015.04.006

[36] Bauerlein, M., The Dumbest Generation: How the Digital Age Stupefies Young Americans and Jeopardizes our Future. Pengun Group, New York, 2008.

[37] Joseph, K, -Y, N. "Ubiquitous Healthcare: Healthcare Systems and Applications Enabled by Mobile and Wireless Technologies". J Converg. 3 (2), pp. $15-20,2012$.

[38] Khamayseh, Y., Mardini, W., Aljawarneh, S., and Yassein, M.B. "Integration of Wireless Technologies in Smart University Campus Environment: Framework Architecture". International Journal of Information and Communication Technology Education. 11 (1), pp. 60 - 74, 2014. http://dx.doi.org/10.4018/ijicte.2015010104

[39] De Sousa Monteiro, B., Gomes, A.S. and Mendes Neto, F.M. "Youubi: Open Software for Ubiqutous Learning". Computers in Human Behavior. In Press http://dx.doi.org/10.1016/j.chb. 2014.09.064

[40] Cuartielles, D. "Opensource Hardware and Education". Lecture Notes in Computer Science. 9083 (2015).

[41] Bargaoui, H. and Bdiwi, R. Smart Classroom: Design of a Gateway for Ubiquitous Classroom. 2014 International Conference on Web and Open Access to Learning. 13 January 2015.

[42] Huang, Y.-M. and Chiu, P.-S. "The Effectiveness of the Meaningful Learning-Based Evaluation for Different Achieving Students in a Ubiquitous Learning Context". Computers and Education. 87 (21 July 2015), pp. $243-253,2015$.

[43] Teo, T. "An Initial Development and Validation of a Digital Natives Assessment Scale (DNAS)". Computer \& Education. 67 (2013), pp. 51-57, 2013.

[44] McVay, M., How To Be A Successful Distance Learning Student: Learning On The Internet. Prentice Hall, New York, 2001.

[45] Boruszko, G. New Technologies and Teaching Comparative Literature. CLCWeb-Comparative Literature and Culture. 15(6), pp. 1-9, 2013.

[46] Kirschner, P.A. and Karpnski, A.C. Facebook and Academic Performance. Computer in Human Behavior. Computer in Human Behavior. 26 (6), pp. 1237-1245, 2010. http://dx.doi.org/10.1016/ j.chb.2010.03.024
[47] Cardoso-Leite, P., Green, C.S., and Bavelier, D. "On the Impact of New Technologies on Multitasking". Developmental Review. 35 (March 2015), pp. 98 - 112, 2015.

[48] Raupach, T., Brown, J., Wieland, A., Anders, S., and Harendza, S. "Should We Pay the Student? A Randomised Trial of Financial Incentives in Medical Education". Medical Teacher. 35(9), pp. 760-766, 2013. http://dx.doi.org/10.3109/0142159X.2013.801942

[49] Barrett, N. and Toma, E.F. "Reward or Punishment? Class Size and Teacher Quality". Economics of Education Review. 35 (August 2013), pp. 41-52, 2013.

[50] Herndon, J.S., Bembenutty, H., and Gill, M.G. "The Role of Delay of Gratification, Substance Abuse, and Violent Behavior on Academic Achievement of Disciplinary Alternative Middle School Students". Personality and Individual Differences. 86 (November 01), pp. 44-49, 2015.

[51] Ponce, P., Polasko, K., and Molina, A. “Technology Transfer Motivation Analysis Based on Fuzzy Type 2 Signal Detection Theory". AI and Society. April 2015, pp. 1-13, 2015.

[52] Sarapin, S.H. and Morris, P.L. (2015). "Faculty and Facebook Friending: Instructor-Student Online Social Communication from the Professors' Perspective". Internet and Higher Education. 27 (17 April 2015), pp. 14-23, 2015. http://dx.doi.org/10.1016/ j.iheduc.2015.04.001

[53] Nicholas Gerlich, R., Drumheller, K., Babb, J., and De'Armond, D. "App Consumption: An Exploratory Analysis of the Uses \& Gratifications of Mobile Apps". Academy of Marketing Studies Journal. 19 (1), pp. 69-79, 2015.

[54] Liu, J. "Globalizing Indigenous Psychology: An East Asian Form of Hierarchical Rationalism with Worldwide Implications". Journal for the Theory of Social Behaviour. 45 (1), pp. 82-94, 2015. http://dx.doi.org/10.1111/jtsb.12058

[55] Mantyaki, M., and Riemer, K. "Digital Natives in Social Virtual Worlds: A Multi-method Study of Gratifications and Social Influences in Habbo Hotel". International Journal of Information Management. 34 (2), pp. 210-220, 2014. http://dx.doi.org/10.1016/ j.ijinfomgt.2013.12.010

[56] Salman, A., and Rahim, S.A. "From Access to Gratification: Towards an Inclusive Digital Society". Asian Social Sciences. 8 (5), pp. 5-15, 2012. http://dx.doi.org/10.5539/ass.v8n5p5

\section{AUTHORS}

Mohd Shafie Rosli is with the Department of Educational Sciences, Mathematics and Creative Multimedia, Universiti Teknologi Malaysia (UTM).. He received his $\mathrm{PhD}$ with research on learning analytic in cognitive engineering from UTM in 2012. He is currently probing into third paradigm computing and applied statistics, especially Structural Equation Model (SEM) (shafierosli@utm.my).

Nor Shela Saleh is with the Department of Human Resource, Faculty of Management, Universiti Teknologi Malaysia, Johor Bahru, Malaysia.. She has wide experience working with AMOS and Structural Equation Model (SEM). Her research interests are in medical learning and SEM application in social science and technology. (shela_saleh87@yahoo.com.my)

Baharuddin Aris is with the Faculty of Education, Universiti Teknologi Malaysia, Johor Bahru, Malaysia (bba@utm.my).

Maizah Hura Ahmad is with the Faculty of Science, Universiti Teknologi Malaysia, Johor Bahru, Malaysia (maizah@utm.my).

Shaharuddin Md. Salleh is with the Faculty of Education, Universiti Teknologi Malaysia, Johor Bahru, Malaysia (p-shah@utm.my).

This work was supported in part by Ministry of Higher Education Malaysia and Universiti Teknologi Malaysia via Research University Grant Scheme. Submitted, 5 October 2015. Published as resubmitted by the authors on 28 January 2016. 